\section{OPEN ACCESS}

Edited by:

Lu Yang,

National Research Council Canada (NRC-CNRC), Canada

Reviewed by:

Przemyslaw Niedzielski,

Adam Mickiewicz University, Poland Honglin Yuan,

Northwest University, China

*Correspondence:

Yue-Heng Yang

yangyueheng@mail.iggcas.ac.cn

Specialty section:

This article was submitted to

Analytical Chemistry,

a section of the journal

Frontiers in Chemistry

Received: 13 August 2020 Accepted: 02 November 2020 Published: 09 December 2020

Citation:

Zhao H, Zhao X-M, Le Roux PJ, Zhang W, Wang H, Xie L-W, Huang C, Wu S-T, Yang J-H, Wu F-Y and

Yang Y-H (2020) Natural Clinopyroxene Reference Materials for in situ Sr Isotopic Analysis via LA-MC-ICP-MS

Front. Chem. 8:594316. doi: $10.3389 /$ fchem.2020.594316

\title{
Natural Clinopyroxene Reference Materials for in situ Sr Isotopic Analysis via LA-MC-ICP-MS
}

\begin{abstract}
Han Zhao 1,2,3 Xin-Miao Zhao 1,2,3, P. J. Le Roux ${ }^{4}$, Wen Zhang ${ }^{5}$, Hao Wang ${ }^{1,2,3}$, Lie-Wen Xie ${ }^{1,2,3}$, Chao Huang ${ }^{1,2,3}$, Shi-Tou Wu ${ }^{1,2,3}$, Jin-Hui Yang ${ }^{1,2,3}$, Fu-Yuan Wu ${ }^{1,2,3}$ and Yue-Heng Yang ${ }^{1,2,3 *}$
\end{abstract}

${ }^{1}$ State Key Laboratory of Lithospheric Evolution, Institute of Geology and Geophysics, Chinese Academy of Sciences, Beijing, China, ${ }^{2}$ Innovation Academy of Earth Science, Chinese Academy of Sciences, Beijing, China, ${ }^{3}$ College of Earth and Planetary Sciences, University of Chinese Academy of Sciences, Beijing, China, ${ }^{4}$ Department of Geological Sciences, University of Cape Town, Cape Town, South Africa, ${ }^{5}$ State Key Laboratory of Geological Processes and Mineral Resources, China University of Geosciences, Wuhan, China

Clinopyroxene is a major host mineral for lithophile elements in the mantle lithosphere, and therefore, its origin is vital for constraints on mantle evolution and melt generation. In situ $\mathrm{Sr}$ isotopic measurement of clinopyroxene has been available since the recent development of laser ablation multicollector inductively coupled plasma mass spectrometry (LA-MC-ICP-MS) in the 2000s. Therefore, there is an increasing demand for natural clinopyroxene reference materials for $\mathrm{Sr}$ isotope microanalysis. In this contribution, we present six natural clinopyroxene reference materials from South Africa (JJG1424) and China (YY09-47, YY09-04, YY09-24, YY12-01, and YY12-02) for Sr isotope microanalysis. The Sr content of these clinopyroxenes ranges from 50 to 340 $\mu \mathrm{g} \mathrm{g}^{-1}$, which covers most natural clinopyroxene compositions. Homogeneity of these potential reference materials were investigated and evaluated in detail over a 2-year period using 193-nm nanosecond and 257-nm femtosecond laser systems coupled to either a Neptune or Neptune Plus MC-ICP-MS. Additionally, the major and trace element of these clinopyroxenes were examined by electron probe microanalyzer (EPMA) as well as solution and laser ICP-MS. The in situ ${ }^{87} \mathrm{Sr} /{ }^{86} \mathrm{Sr}$ values obtained for the six natural clinopyroxene reference materials agree well with data obtained using the thermal ionization mass spectrometer (TIMS) method. The Sr isotopic stability and homogeneity of these clinopyroxenes make them potential reference materials for in situ Sr microanalysis to correct instrumental fractionation or as quality control materials for analytical sessions. The new $\mathrm{Sr}$ isotope data provided here might be beneficial for microbeam analysis in the geochemical community.

Keywords: clinopyroxene, in situ, ${ }^{87} \mathrm{Sr} /{ }^{86} \mathrm{Sr}$ analysis, LA-MC-ICP-MS, natural reference material 


\section{HIGHLIGHTS}

- Six natural clinopyroxene reference materials available for in situ $\mathrm{Sr}$ isotope analysis.

- The Sr content covers most natural clinopyroxene compositions.

- Homogeneous investigation using nano- and femtosecond LAMC-ICP-MS.

- In situ ${ }^{87} \mathrm{Sr} /{ }^{86} \mathrm{Sr}$ values in good agreement with those data by TIMS method.

\section{INTRODUCTION}

Clinopyroxene (CPX), a common Ca-rich mineral in mantle rock, is a principal host of $\mathrm{Sr}$, and its $\mathrm{Sr}$ isotopic composition can reveal geological processes in the mantle lithosphere, such as (1) melt refertilization of the mantle (Tang et al., 2011, 2012; Zou et al., 2014; Liu et al., 2016); (2) degree of partial melting the mantle experienced (Griffin and Brueckner, 1985; Norman, 2001; Liu et al., 2016); and (3) metasomatic agents affecting the mantle (Rudnick et al., 2004; Wu et al., 2006; Sapienza et al., 2008; Touron et al., 2008; Sun et al., 2012; Xu et al., 2013; Tang et al., 2017; Aulbach et al., 2019). In summary, clinopyroxene Sr isotopes may therefore be a powerful tracer of subducted altered oceanic crust (Xu et al., 2003; Gao and Zhou, 2013).

In situ $\mathrm{Sr}$ isotope measurement via ablation multicollector inductively coupled plasma mass spectrometry (LA-MCICP-MS) for clinopyroxene has been growing rapidly. For example, the first study demonstrated isotopic heterogeneity at the scale of individual grains in peridotite xenoliths and multiple measurements of the same grain; however, it indicated intragrain $\mathrm{Sr}$ isotopic disequilibrium (Schmidberger et al., 2003). Subsequently, Jackson and Hart (2006) reported in situ $\mathrm{Sr}$ isotopes in melt inclusions hosted by olivine phenocrysts and observed melts from high ${ }^{3} \mathrm{He} /{ }^{4} \mathrm{He}$ and EM II-type mantle end members, respectively. Sun et al. (2012) performed an in situ Sr isotopes for clinopyroxene in mantle xenoliths from Hebi, central North China Craton (NCC), and concluded that the clinopyroxene were crystallized from metasomatic melts. $\mathrm{Xu}$ et al. (2013) conducted in situ Sr isotopic composition of peridotite xenoliths from Kuandian and investigated Pacific slab subduction-related mantle modification of clinopyroxene beneath the eastern NCC.

Although solution-based thermal ionization mass spectrometer (TIMS) or MC-ICP-MS method, in particular, is suitable for high precision Sr isotope determination, after laborious and time-consuming chemical purification (Chu et al., 2009; Yang et al., 2010, 2011, 2012; Li et al., 2012; Raddatz et al., 2013; Xu et al., 2020), LA-MC-ICP-MS is extensively applied to analyze $\mathrm{Sr}$ isotope on account of its rapid sample preparation, high throughput, and small volume consumption (Schmidberger et al., 2003, 2007; Jackson and Hart, 2006; Fietzke et al., 2008; Konter and Storm, 2014). Moreover, in situ Sr isotopic analysis can decipher more significant information than common whole rock analysis in high resolution. Currently, LA-MC-ICP-MS is a well-developed technique to measure ${ }^{87} \mathrm{Sr} /{ }^{86} \mathrm{Sr}$ in relatively high Sr geological samples (>500 $\mathrm{Mg} \mathrm{g}^{-1} \mathrm{Sr}$, e.g., apatite, perovskite, plagioclase, eudialyte, bastnaesite) (Yang et al., 2009a, 2011, 2019; Wu et al., 2010; Kimura et al., 2013; Konter and Storm, 2014; Tong et al., 2016; Zhang et al., 2018). Nevertheless, for low Sr-content minerals, such as clinopyroxene from most peridotite xenoliths, it is still challenging (Waight et al., 2002; Woodhead et al., 2005; Copeland et al., 2008; Vroon et al., 2008; Jochum et al., 2009; Lin et al., 2015).

According to the literature data from Georoc (Figure 1), the $\mathrm{Sr}$ content of natural clinopyroxene samples mainly distributed between 50 and $350 \mu \mathrm{g} \mathrm{g}^{-1}$. Although a synthesized clinopyroxene glass with added $\mathrm{Sr}\left(\mathrm{CPX} 05 \mathrm{G}, \sim 518 \mu \mathrm{g} \mathrm{g}^{-1} \mathrm{Sr}\right.$ ) was developed as an in-house reference material, the content of $\mathrm{Sr}$ is higher than that of most natural clinopyroxene, and a limitation is its unavailability for other users (Tong et al., 2016). There is still lack of accessible clinopyroxene reference material for $\mathrm{Sr}$ isotope microanalysis. Despite a few published papers about in situ $\mathrm{Sr}$ analysis of clinopyroxene, the shortage of reference materials hinders the development of in situ $\mathrm{Sr}$ isotope measurements for clinopyroxene (Waight et al., 2002; Bizzarro et al., 2003; Schmidberger et al., 2003; Hart et al., 2005; Sun et al., 2012; Xu et al., 2013; Su et al., 2015; Tong et al., 2016; Deng et al., 2017; Tang et al., 2019).

Herein, we investigated whether the homogeneity of $\mathrm{Sr}$ isotopes for six natural clinopyroxene from South Africa (JJG1424) and China (YY09-47, YY09-04, YY09-24, YY1201, and YY12-02), which covers a range of 50-350 $\mathrm{g} \mathrm{g} \mathrm{g}^{-1}$, corresponds well to the natural distribution, at the micrometer scale, using MC-ICP-MS coupled with nano- and femtosecond laser over a 2-year period. Precise $\mathrm{Sr}$ isotope compositions of these samples were also determined using classic TIMS or solution MC-ICP-MS methods. Meanwhile, the major and trace element of these clinopyroxenes were examined by EPMA, ICPMS based on solution, and laser sampling. Our work indicates that these six natural minerals might be employed as potential reference materials for in situ Sr isotope analysis.

\section{ANALYTICAL METHODS}

All six samples were prepared and mounted in epoxy resin blocks and polished to expose the interior of the crystals prior to analysis at the State Key Laboratory of Lithospheric Evolution (SKLLE), Institute of Geology and Geophysics, Chinese Academy of Sciences (IGGCAS). For comparison, one analytical session for in situ Sr isotope was performed at the State Key Laboratory of Geological Process and Mineral Resources (GPMR), China University of Geosciences (Wuhan), China.

\section{Sample Description}

Five of the samples were separated from lherzolite xenoliths entrained in the Yangyuan, in the Central Zone of the NCC (Zhao et al., 2015, 2017), and the other is from South Africa (Class and le Roex, 2011). According to the mineralogical and geochemical features of the clinopyroxene, they are Cr-diopside.

\section{Major Element by EPMA}

Major element composition of samples and backscattered electron (BSE) images were obtained from polished thin sections 


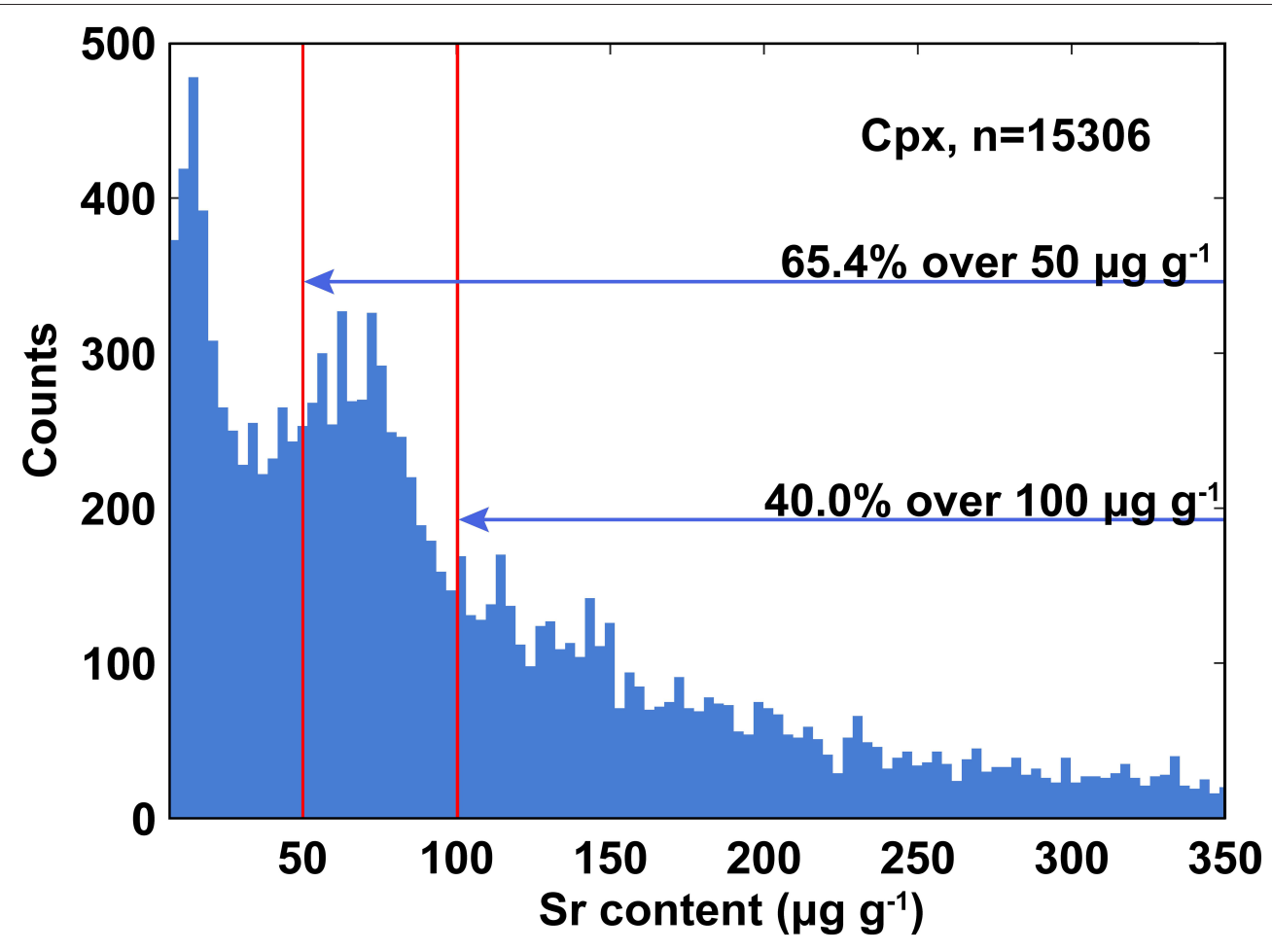

FIGURE 1 | Sr contents ( $\mathrm{g} \mathrm{g} \mathrm{g}^{-1}$ ) distribution range over 10,000 published clinopyroxenes (based on data from Georoc).

using a JEOL-JXA8100 electron probe microanalyzer (EPMA) at IGGCAS. The operating conditions were as follows: $15 \mathrm{kV}$ accelerating voltage, $12 \mathrm{nA}$ beam current, $5 \mu \mathrm{m}$ beam spot, and $10-30$ s counting time on peak. Natural clinopyroxene and synthetic oxides were used for data correction, and the precision of all analyzed elements is better than $1.5 \%$.

\section{Trace Element Compositions Using}

\section{Solution or Laser Ablation ICP-MS Analysis}

Solution trace element contents in clinopyroxene were determined using a sector field (SF) ICP-MS (Finnigan MAT Element I) after digestion of about $40 \mathrm{mg}$ of sample using a mixture of ultrapure $1 \mathrm{ml} \mathrm{HF}$ and $0.8 \mathrm{ml} \mathrm{HNO}_{3}$ in Teflon bombs. After dissolution, the solution in the bomb is transferred into a polyethylene terephthalate (PET) bottle, which is weighed accurately to $50 \mathrm{~g}$ by addition of a $2 \% \mathrm{HNO}_{3}$ solution with 10 $\mathrm{ng} \mathrm{g}^{-1}$ in internal standard addition. The carrier and makeup gas flows were optimized daily to obtain a sensitivity of ${ }^{89} \mathrm{Y}$ over $20 \mathrm{Mcps} / \mu \mathrm{g} \mathrm{g}^{-1}$ while holding the $\mathrm{ThO}^{+} / \mathrm{Th}^{+}$ratio below $0.5 \%$. Indium was used as an internal standard to correct for matrix effects and instrumental drift. A Chinese GSR-3 silicate reference material was measured to monitor the accuracy of the analytical procedure, and the results are in consistence with recommended values. The results are adopted as reference values for LA-ICP-MS analyses. According to the result of GSR-3, individual elemental precision is generally better than $5 \%$.

An Agilent 7500a ICP-MS coupled with a 193-nm ArF excimer laser ablation system was employed to measure trace element. Helium was used as the carrier gas through the ablation cell and mixed with argon downstream of the ablation cell (Table 1). Prior to measurement, the pulse/analog (P/A) factor of the detector was calibrated using a tuning solution. The carrier and makeup gas flows were daily optimized to obtain maximum signal intensity for ${ }^{238} \mathrm{U}^{+}$while keeping the $\mathrm{ThO}^{+} / \mathrm{Th}^{+}$ratio below $0.5 \%$. All LA-ICP-MS determinations were conducted using time-resolved analysis in fast, peak jumping mode. Each spot analysis consisted of an $\sim 20$-s background and 60-s sample data acquisition. The dwell time for each isotope was set at $6 \mathrm{~ms}$ for $\mathrm{Rb}, \mathrm{Sr}, \mathrm{Ba}, \mathrm{Nb}, \mathrm{Ta}, \mathrm{Zr}, \mathrm{Hf}, \mathrm{Pb}$, and rare earth element (REE) and $10 \mathrm{~ms}$ for ${ }^{232} \mathrm{Th}$ and ${ }^{238} \mathrm{U}$. Trace element concentrations were calibrated against the NIST SRM 612 standard glass reference material with ${ }^{43} \mathrm{Ca}$ as the internal standard element and using USGS BCR-2G glass as a quality monitor. Data reduction, including concentration determinations, method detection limits, and internal uncertainties were obtained using the GLITTER laser ablation software (Achterbergh et al., 2001).

\section{In situ Sr Isotopic Analysis by Laser Ablation MC-ICP-MS}

Neptune or Neptune Plus MC-ICP-MS with either a 193-nm ArF excimer or 257-nm femtosecond laser was employed to measure Sr isotopes at IGGCAS, Beijing and GPMR, Wuhan (Yang et al., 2014, 2019; Zhang et al., 2018, 2020). A spot size of 60-160 $\mu \mathrm{m}$ was used with a $6-8 \mathrm{~Hz}$ repetition rate and an energy density of $\sim 8 \mathrm{~J} \mathrm{~cm}^{-2}$, depending on the $\mathrm{Sr}$ content of sample (Table 1 ). The $\mathrm{Sr}$ isotopic data were collected by static multicollection 
TABLE 1 | Typical instrumental parameters for trace element and Sr isotopic measurements by LA-(MC)-ICP-MS.

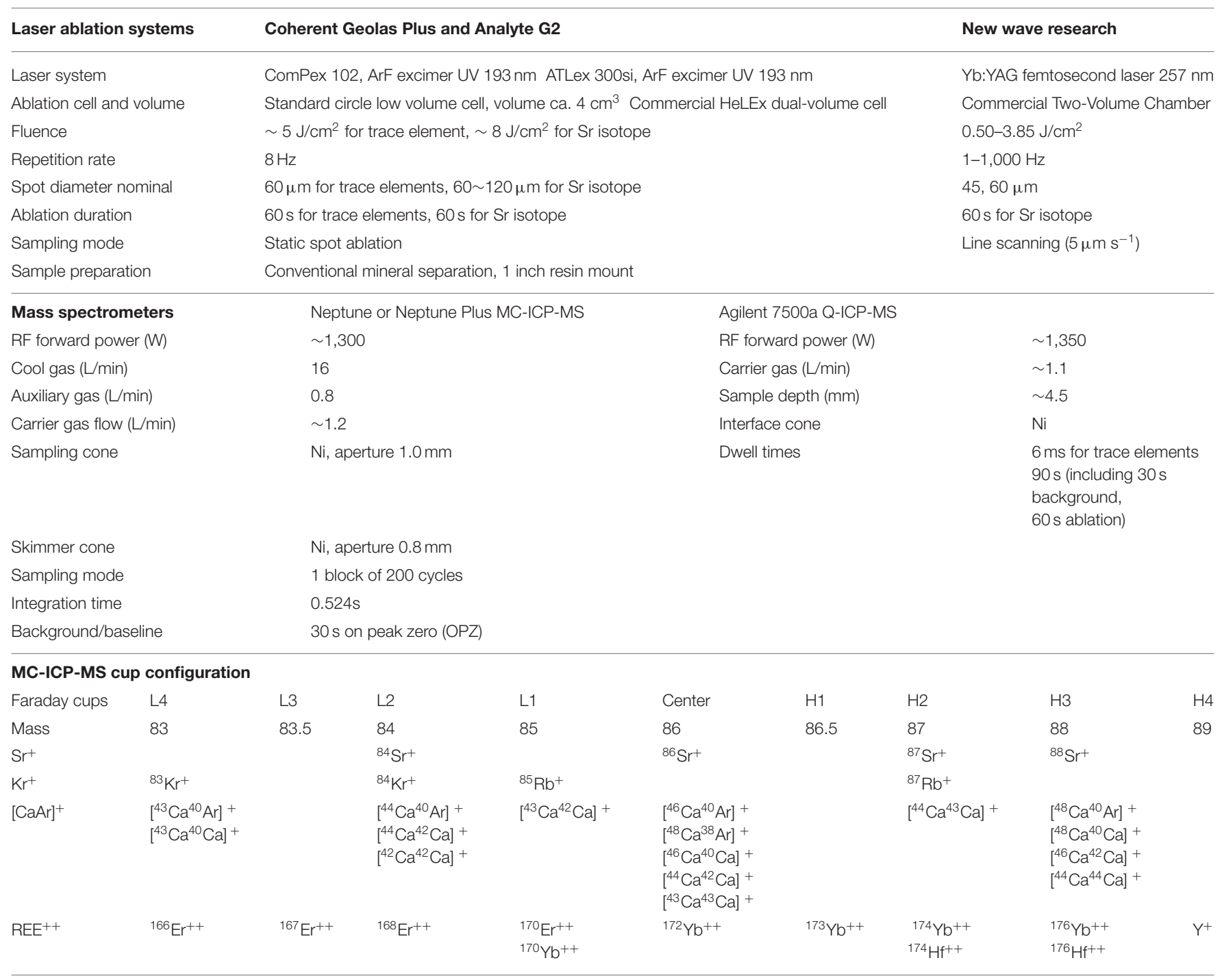

\section{Data processing}

Gas blank

Calibration strategy

30 s on-peak zero subtracted

Data processing package used

NIST 612 used as external standard and ${ }^{43} \mathrm{Ca}$ used as internal standard for calibrating trace elements, ${ }^{83} \mathrm{Kr} /{ }^{84} \mathrm{Kr}=0.20175$, ${ }^{83} \mathrm{Kr} /{ }^{86} \mathrm{Kr}=0.66474,{ }^{85} \mathrm{Rb} /{ }^{87} \mathrm{Rb}=2.5926$; (Christensen et al., 1995; Bizzarro et al., 2003; Woodhead et al., 2005)

For trace elements, Glitter software was used for isotopic and elemental fractionation, instrumental mass bias calibration and uncertainty propagation. For Sr isotope, an in house Microsoft Excel macro written in VBA (Visual Basic for Applications) was used for Sr isotope mass fraction correction, interference correction and uncertainty propagation.

mode, using X skimmer and Jet sample cone. Prior to laser measurement, the MC-ICP-MS was optimized using a standard solution to obtain maximum sensitivity. The integral process of data acquisition has one block of 200 cycles, and the integration time is $0.524 \mathrm{~s}$ per cycle. A typical data acquisition cycle consisted of a 30-s measurement of the $\mathrm{Kr}$ gas blank with the laser off, followed by $60 \mathrm{~s}$ of measurement with the laser on. In this work, YY09-47, YY09-24, and YY12-01 clinopyroxene samples were measured after every 10 unknown samples for external calibration (Yang et al., 2014, 2019; Lin et al., 2016; Zhang et al., 2018, 2020).
Data reduction was conducted offline and the potential isobaric interferences were accounted for in the following order: $\mathrm{Kr}^{+}$and $\mathrm{Rb}^{+}$. First, the interference of ${ }^{84} \mathrm{Kr}$ and ${ }^{86} \mathrm{Kr}$ on ${ }^{84} \mathrm{Sr}$ and ${ }^{86} \mathrm{Sr}$, respectively, were removed using the $30-\mathrm{s} \mathrm{Kr}$ gas baseline measurement. The isobaric interference correction of ${ }^{84} \mathrm{Kr}$ and ${ }^{86} \mathrm{Kr}$ on ${ }^{84} \mathrm{Sr}$ and ${ }^{86} \mathrm{Sr}$ was carried out using the natural $\mathrm{Kr}$ isotopic ratios $\left({ }^{83} \mathrm{Kr} /{ }^{84} \mathrm{Kr}=0.20175,{ }^{83} \mathrm{Kr} /{ }^{86} \mathrm{Kr}=\right.$ 0.66474; Christensen et al., 1995; Bizzarro et al., 2003). Second, the natural ratio of ${ }^{85} \mathrm{Rb} /{ }^{87} \mathrm{Rb}$ (2.5926) was used to correct for isobaric interference of ${ }^{87} \mathrm{Rb}$ on ${ }^{87} \mathrm{Sr}$ by the exponential law, assuming that $\mathrm{Rb}$ has the same mass discrimination behavior 


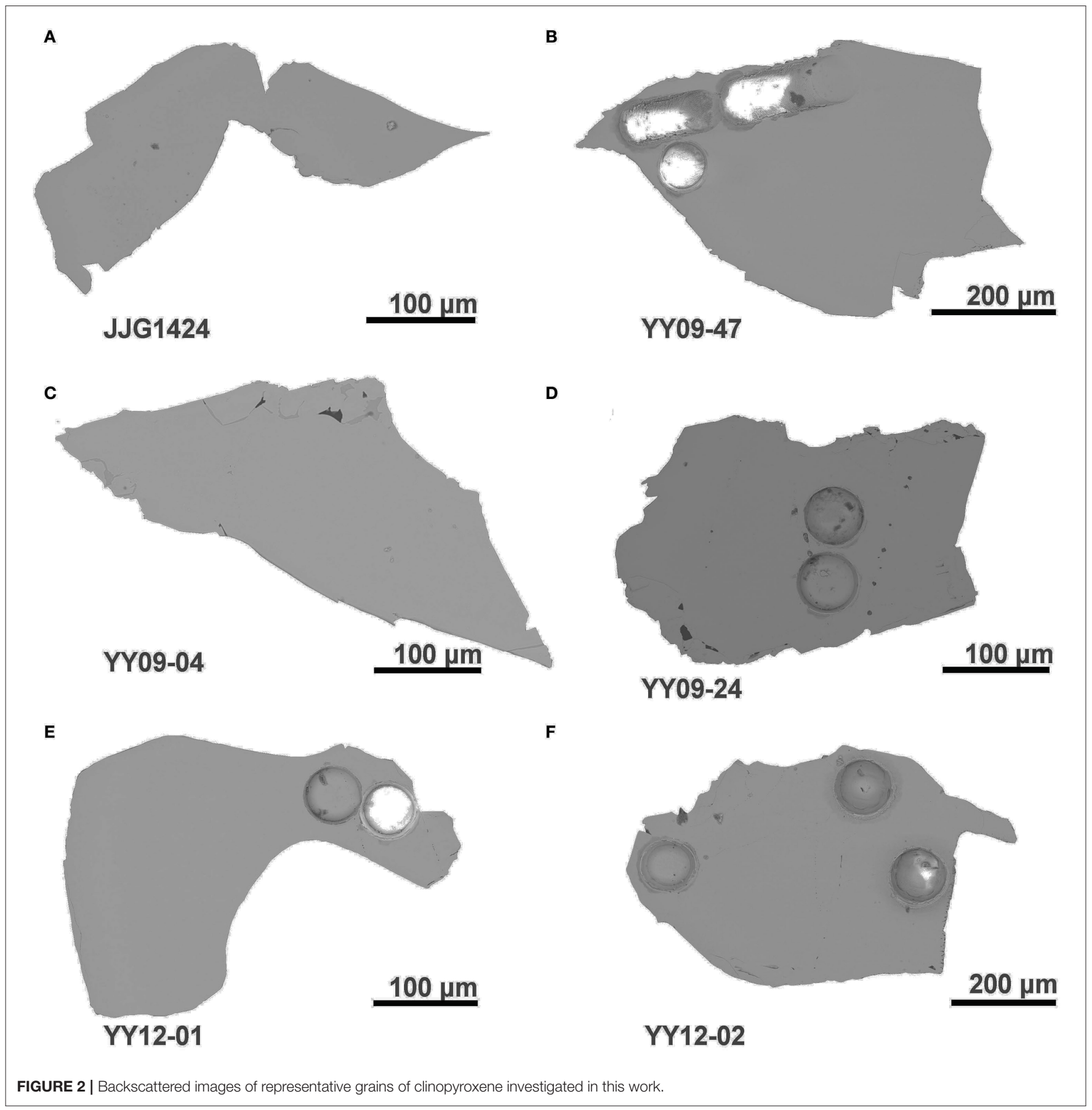

as Sr (Woodhead et al., 2005). It is observed that the obtained ${ }^{87} \mathrm{Rb} /{ }^{87} \mathrm{Sr}$ ratio is typically $<0.001$ during in situ clinopyroxene $\mathrm{Sr}$ analysis, indicating that the radiogenic ${ }^{87} \mathrm{Sr}$ contribution is negligible (Yang et al., 2011). Additionally, our previous work demonstrated that $\mathrm{Ca}$ argides and dimers had an insignificant influence on $\mathrm{Sr}$ isotope analysis using a Neptune MC-ICP-MS (Yang et al., 2011); this observation is also strongly supported by other studies (Ramos et al., 2004; Vroon et al., 2008). Therefore, interferences from $\mathrm{Ca}$ argides or dimers are not considered further in this work. Meanwhile, we also monitored the ${ }^{167} \mathrm{Er}^{2+},{ }^{171} \mathrm{Yb}^{2+}$, and ${ }^{173} \mathrm{Yb}^{2+}$ at masses $83.5,85.5$, and 86.5, indicating negligible interference of double-charged ion. Finally, the ${ }^{87} \mathrm{Sr} /{ }^{86} \mathrm{Sr}$ ratios were calculated and normalized from the interference-corrected ${ }^{86} \mathrm{Sr} /{ }^{88} \mathrm{Sr}$ ratio using the exponential law. The whole data reduction procedure was performed using an in-house Excel Visual Basic for Applications (VBA) macro program (Horstwood et al., 2008, 2016; Zhang et al., 2018; Zhang et al., 2020). 


\section{Solution Sr Isotope Measurement by Isotope Dilution Thermal Ionization Mass Spectrometer}

$\mathrm{Rb}$ and $\mathrm{Sr}$ concentration and isotopic compositions of the clinopyroxenes were measured using a Thermo Scientific Triton

TABLE 2 | Major element (wt\%) composition of the clinopyroxene investigated in this study.

\begin{tabular}{|c|c|c|c|c|c|c|}
\hline Sample & JJG1424 & YY09-47 & YY09-04 & YY09-24 & YY12-01 & YY12-02 \\
\hline $\mathrm{SiO}_{2}$ & 54.77 & 53.19 & 52.57 & 52.43 & 52.96 & 53.27 \\
\hline $\mathrm{TiO}_{2}$ & 0.25 & 0.12 & 0.36 & 0.46 & 0.34 & 0.21 \\
\hline $\mathrm{Al}_{2} \mathrm{O}_{3}$ & 2.91 & 5.69 & 5.62 & 6.67 & 6.72 & 5.13 \\
\hline $\mathrm{Cr}_{2} \mathrm{O}_{3}$ & 0.79 & 1.45 & 0.96 & 0.98 & 0.27 & 1.08 \\
\hline $\mathrm{FeO}$ & 1.60 & 2.60 & 2.58 & 4.14 & 2.63 & 2.50 \\
\hline $\mathrm{MnO}$ & 0.06 & 0.06 & 0.04 & 0.11 & 0.08 & 0.08 \\
\hline $\mathrm{MgO}$ & 16.22 & 14.85 & 15.09 & 14.64 & 15.33 & 15.62 \\
\hline $\mathrm{CaO}$ & 21.72 & 19.02 & 19.94 & 18.03 & 18.74 & 20.65 \\
\hline $\mathrm{Na}_{2} \mathrm{O}$ & 1.67 & 2.28 & 1.60 & 1.90 & 2.02 & 1.33 \\
\hline $\mathrm{NiO}$ & 0.02 & 0.04 & 0.04 & 0.07 & - & - \\
\hline Toal & 100.03 & 99.30 & 98.80 & 99.50 & 99.20 & 99.90 \\
\hline $\mathrm{Mg \#}$ & 90.1 & 91.1 & 91.3 & 86.3 & 90.3 & 91.8 \\
\hline Cr\# & 10.5 & 14.6 & 10.3 & 8.9 & 2.6 & 12.4 \\
\hline
\end{tabular}

Plus TIMS in IGGCAS. Clinopyroxenes from a number of samples were handpicked for radiogenic isotope analysis using the isotope dilution method detailed elsewhere (Li et al., 2012, 2019). About $50 \mathrm{mg}$ of each sample was weighted into a 7$\mathrm{ml}$ round bottom Savillex ${ }^{\mathrm{TM}}$ Teflon screw-top capsule and $3.0 \mathrm{ml}$ of a mixed acid added, composed of $29 \mathrm{M} \mathrm{HF}+0.3 \mathrm{ml}$ $14 \mathrm{M} \mathrm{HNO}_{3}+0.3 \mathrm{ml} 11.8 \mathrm{M} \mathrm{HClO}_{4}$ with the addition of a ${ }^{87} \mathrm{Rb}-{ }^{84} \mathrm{Sr}$ tracer. The samples were dissolved on a hotplate at $180^{\circ} \mathrm{C}$ for 7 days. Each capsule was opened and evaporated to fume $\mathrm{HClO}_{4}$ after cooling. The dissolved sample solution was then evaporated to dryness at ca. $120^{\circ} \mathrm{C}$. After that, the samples were redissolved once more in $1.0 \mathrm{ml}$ of $6 \mathrm{M} \mathrm{HCl}$ and reheated to $180^{\circ} \mathrm{C}$ for several hours to eliminate fluoride complexes. Finally, the vials were opened, and the resulting sample solution was evaporated to dryness and redissolved with $1.0 \mathrm{ml}$ of $2.5 \mathrm{M} \mathrm{HCl}$ on a hot plate at $120^{\circ} \mathrm{C}$. Next, elements were separated on AG50W-X12 cation resin columns (Li et al., 2012, 2019). Rock reference materials BCR-2 and BHVO-2 from USGS were measured to monitor the accuracy of the analytical procedure, and our results [BCR-2: 46.2 $\mu \mathrm{g} \mathrm{g}^{-1} \mathrm{Rb}$ and $338 \mu \mathrm{g} \mathrm{g}^{-1} \mathrm{Sr}, 0.705004 \pm 0.000008(2 \mu)$ of ${ }^{87} \mathrm{Sr} /{ }^{86} \mathrm{Sr}$ ratio; BHVO-2: $8.9 \mu \mathrm{g} \mathrm{g}^{-1} \mathrm{Rb}$ and $378 \mu \mathrm{g}$ $\mathrm{g}^{-1} \mathrm{Sr}, 0.703419 \pm 0.0000013(2 \mu)$ of ${ }^{87} \mathrm{Sr} /{ }^{86} \mathrm{Sr}$ ratio] are almost identical to recommended values (Raczek et al., 2003; Yang et al., 2010, 2012).

TABLE 3 | Trace element $\left(\mu \mathrm{g} \mathrm{g}^{-1}\right)$ composition of clinopyroxene measured by solution and laser ICP-MS.

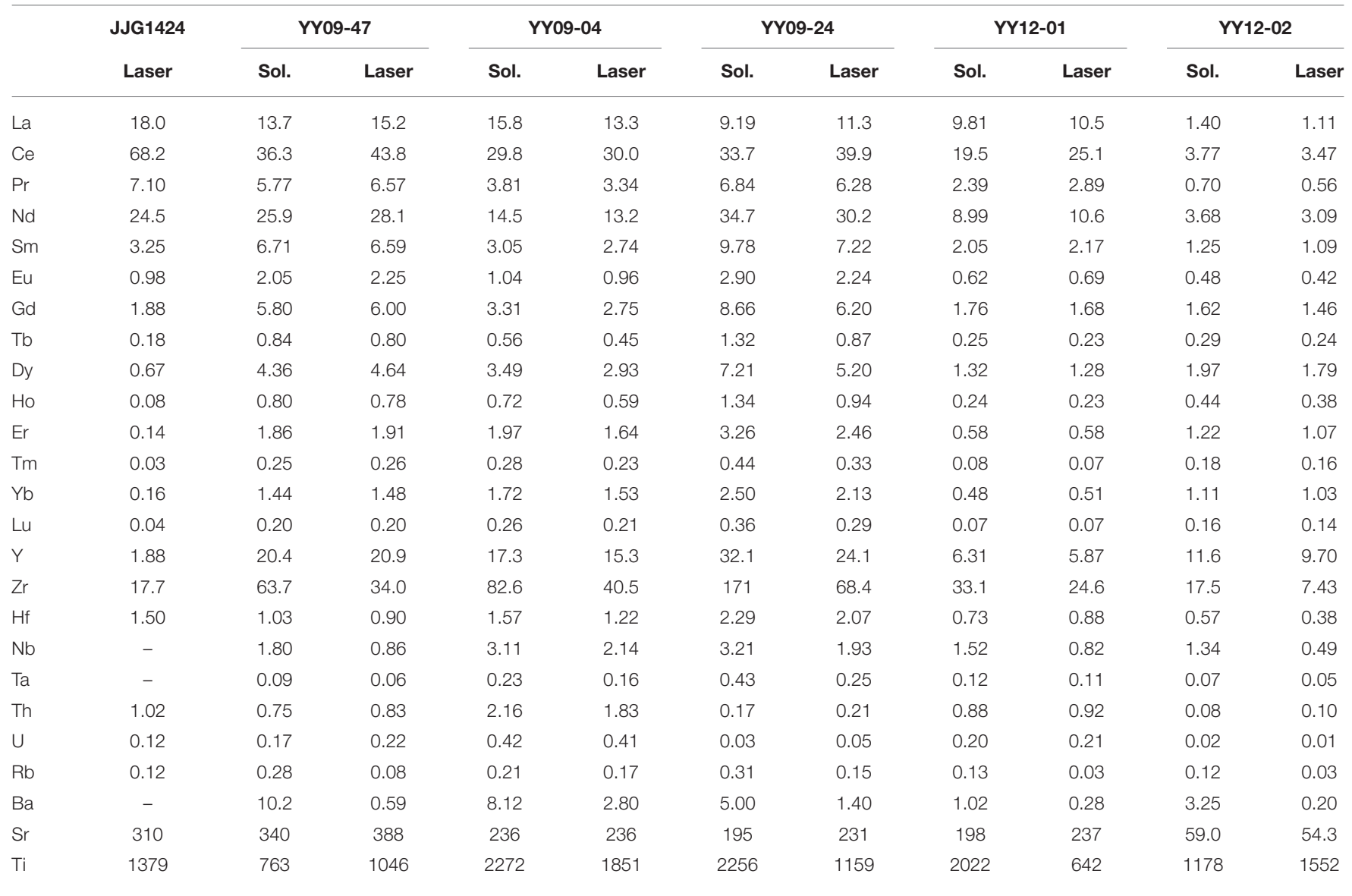



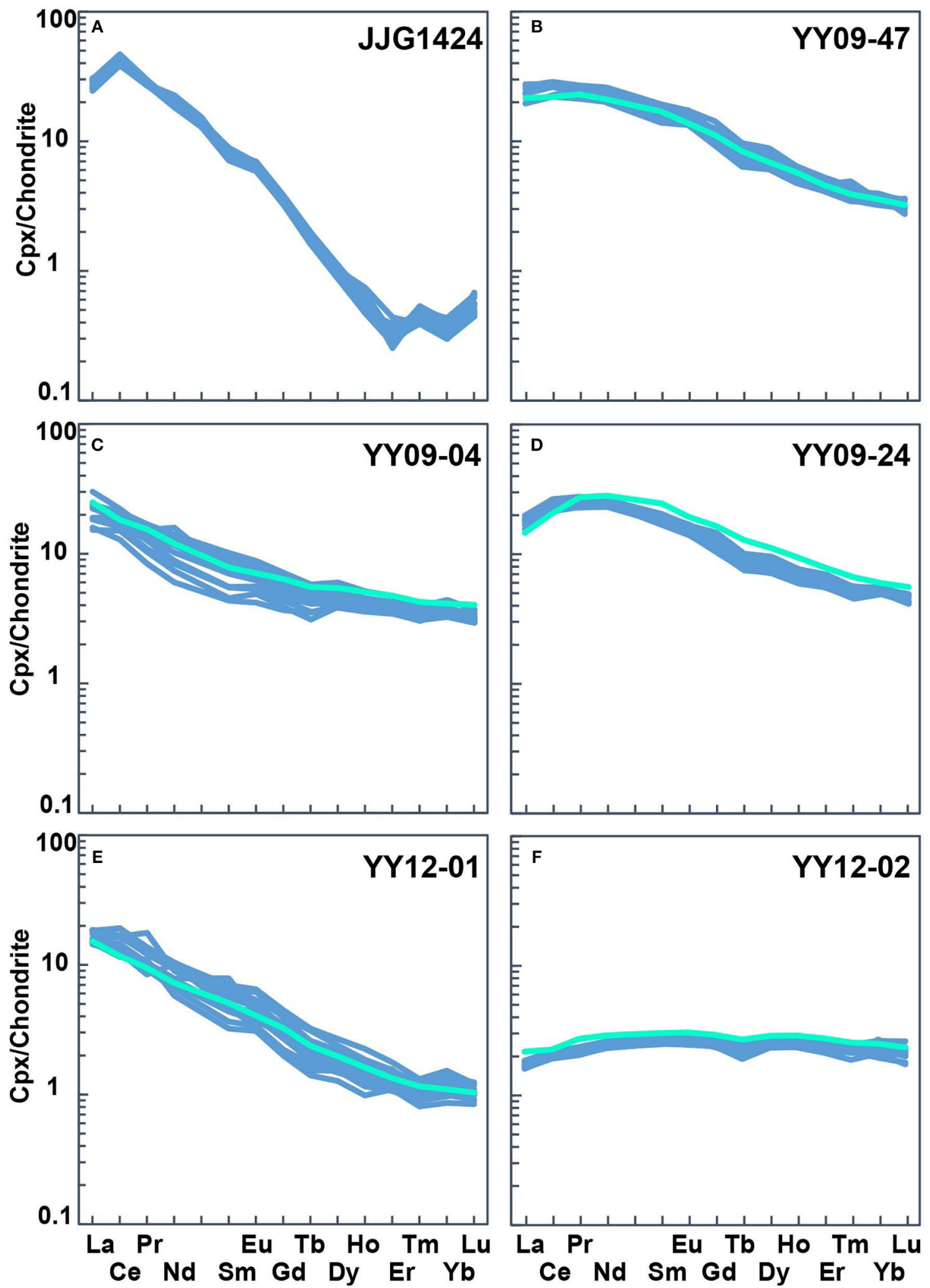

FIGURE 3 | Rare earth element (REE) patterns of clinopyroxenes (A-F), normalized to chondrite after (McDonough and Sun, 1995). The bright green lines are given by solution ICP-MS in (B-F) (Zhao et al., 2015), and the blue lines are measured by LA-ICP-MS. 
TABLE 4 | Summary of Sr isotopic ratios for six natural clinopyroxenes measured in five analytical sessions.

\begin{tabular}{|c|c|c|c|c|c|c|c|c|c|c|c|}
\hline Sample & Sessions & Date & $\begin{array}{l}\text { Spot size } \\
(\mu \mathrm{m})\end{array}$ & $\begin{array}{l}{ }^{88} \mathrm{Sr} \\
\text { intensity } \\
\text { (V) }\end{array}$ & ${ }^{84} \mathrm{Sr} /{ }^{86} \mathrm{Sr}$ & $2 s$ & ${ }^{87} \mathrm{Sr} /{ }^{86} \mathrm{Sr}$ & $2 s$ & $\mathbf{n}$ & MC-ICP-MS + Laser & Labs \\
\hline \multirow[t]{6}{*}{ JJG1424 } & Session 1 & 2017.02 .16 & 120 & 0.90 & 0.0570 & 0.0010 & 0.70501 & 0.00021 & 18 & Neptune + Geolas & IGGCAS \\
\hline & Session 2 & 2017.05 .06 & 110 & 0.87 & 0.0568 & 0.0012 & 0.70493 & 0.00031 & 19 & Neptune Plus + G2 & IGGCAS \\
\hline & Session 3 & 2019.03.28 & 120 & 1.05 & 0.0569 & 0.0010 & 0.70495 & 0.00019 & 17 & Neptune + Geolas & IGGCAS \\
\hline & Session 4 & 2019.07.06 & 90 & 1.30 & 0.0575 & 0.0008 & 0.70506 & 0.00034 & 30 & Neptune Plus + Geolas & IGGCAS \\
\hline & Session 5 & 2019.05.28 & 60 & 3.03 & 0.0578 & 0.0006 & 0.70481 & 0.00022 & 18 & Neptune Plus + NWR fs & CUG \\
\hline & Mean & & & 1.62 & 0.0573 & 0.0012 & 0.70494 & 0.00031 & 102 & & \\
\hline \multirow[t]{6}{*}{ YY09-47 } & Session 1 & 2017.02.16 & 120 & 0.79 & 0.0560 & 0.0024 & 0.70403 & 0.00030 & 20 & Neptune + Geolas & IGGCAS \\
\hline & Session 2 & 2017.05.06 & 110 & 0.69 & 0.0557 & 0.0018 & 0.70401 & 0.00026 & 20 & Neptune Plus + G2 & IGGCAS \\
\hline & Session 3 & 2019.03.28 & 120 & 1.08 & 0.0555 & 0.0021 & 0.70403 & 0.00020 & 28 & Neptune + Geolas & IGGCAS \\
\hline & Session 4 & 2019.07.06 & 90 & 1.34 & 0.0564 & 0.0010 & 0.70406 & 0.00013 & 21 & Neptune Plus + Geolas & IGGCAS \\
\hline & Session 5 & 2019.05 .28 & 60 & 2.29 & 0.0573 & 0.0002 & 0.70408 & 0.00015 & 35 & Neptune Plus + NWR fs & CUG \\
\hline & Mean & & & 1.36 & 0.0563 & 0.0021 & 0.70405 & 0.00021 & 124 & & \\
\hline \multirow[t]{6}{*}{ YY09-04 } & Session 1 & 2017.02 .16 & 120 & 0.57 & 0.0568 & 0.0016 & 0.70338 & 0.00040 & 14 & Neptune + Geolas & IGGCAS \\
\hline & Session 2 & 2017.05 .06 & 110 & 0.54 & 0.0555 & 0.0020 & 0.70321 & 0.00035 & 15 & Neptune Plus + G2 & IGGCAS \\
\hline & Session 3 & 2019.03 .28 & 90 & 0.60 & 0.0551 & 0.0024 & 0.70324 & 0.00041 & 13 & Neptune + Geolas & IGGCAS \\
\hline & Session 4 & 2019.07.06 & 90 & 1.00 & 0.0581 & 0.0023 & 0.70345 & 0.00038 & 22 & Neptune Plus + Geolas & IGGCAS \\
\hline & Session 5 & 2019.05 .28 & 60 & 1.27 & 0.0575 & 0.0003 & 0.70337 & 0.00033 & 17 & Neptune Plus + NWR fs & CUG \\
\hline & Mean & & & 0.83 & 0.0568 & 0.0030 & 0.70334 & 0.00041 & 81 & & \\
\hline \multirow[t]{6}{*}{ YY09-24 } & Session 1 & 2017.02 .16 & 120 & 0.57 & 0.0556 & 0.0022 & 0.70348 & 0.00044 & 17 & Neptune + Geolas & IGGCAS \\
\hline & Session 2 & 2017.05.06 & 110 & 0.52 & 0.0552 & 0.0022 & 0.70333 & 0.00039 & 17 & Neptune Plus + G2 & IGGCAS \\
\hline & Session 3 & 2019.03.28 & 90 & 0.63 & 0.0566 & 0.0042 & 0.70354 & 0.00034 & 23 & Neptune + Geolas & IGGCAS \\
\hline & Session 4 & 2019.07.06 & 90 & 0.76 & 0.0569 & 0.0012 & 0.70359 & 0.00025 & 20 & Neptune Plus + Geolas & IGGCAS \\
\hline & Session 5 & 2019.05 .28 & 60 & 1.37 & 0.0577 & 0.0011 & 0.70349 & 0.00027 & 25 & Neptune Plus + NWR fs & CUG \\
\hline & Mean & & & 0.81 & 0.0565 & 0.0031 & 0.70349 & 0.00037 & 102 & & \\
\hline \multirow[t]{6}{*}{ YY12-01 } & Session 1 & 2017.02 .16 & 120 & 0.58 & 0.0559 & 0.0029 & 0.70338 & 0.00051 & 20 & Neptune + Geolas & IGGCAS \\
\hline & Session 2 & 2017.05 .06 & 110 & 0.64 & 0.0564 & 0.0026 & 0.70340 & 0.00051 & 15 & Neptune Plus + G2 & IGGCAS \\
\hline & Session 3 & 2019.03.28 & 90 & 0.41 & 0.0560 & 0.0032 & 0.70348 & 0.00028 & 16 & Neptune + Geolas & IGGCAS \\
\hline & Session 4 & 2019.07.06 & 90 & 0.95 & 0.0578 & 0.0012 & 0.70369 & 0.00027 & 18 & Neptune Plus + Geolas & IGGCAS \\
\hline & Session 5 & 2019.05 .28 & 60 & 1.67 & 0.0578 & 0.0006 & 0.70358 & 0.00022 & 20 & Neptune Plus + NWR fs & CUG \\
\hline & Mean & & & 0.87 & 0.0568 & 0.0029 & 0.70358 & 0.00043 & 99 & & \\
\hline \multirow[t]{6}{*}{ YY12-02 } & Session 1 & 2017.02 .16 & 150 & 0.16 & 0.0542 & 0.0086 & 0.70321 & 0.00082 & 17 & Neptune + Geolas & IGGCAS \\
\hline & Session 2 & 2017.05 .06 & 130 & 0.16 & 0.0522 & 0.0074 & 0.70361 & 0.00115 & 17 & Neptune Plus + G2 & IGGCAS \\
\hline & Session 3 & 2019.03.28 & 110 & 0.12 & 0.0548 & 0.0069 & 0.70295 & 0.00105 & 15 & Neptune + Geolas & IGGCAS \\
\hline & Session 4 & 2019.07.06 & 90 & 0.34 & 0.0540 & 0.0037 & 0.70332 & 0.00093 & 16 & Neptune Plus + Geolas & IGGCAS \\
\hline & Session 5 & 2019.05 .28 & 60 & 0.49 & 0.0622 & 0.0007 & 0.70327 & 0.00086 & 21 & Neptune Plus + NWR fs & CUG \\
\hline & Mean & & & 0.27 & 0.0561 & 0.0106 & 0.70328 & 0.00103 & 89 & & \\
\hline
\end{tabular}

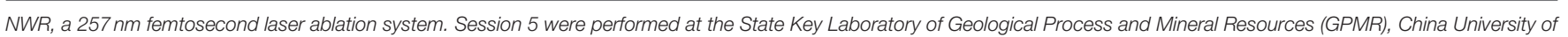
Geosciences (Wuhan), China. Bold values indicates the mean values for every sample above.

\section{RESULTS AND DISCUSSION}

The grains generally appear to be structural homogeneous as indicated by backscattered microscopy (Figure 2). The average and ranges of the major and trace elements for these six clinopyroxenes are listed in Tables 2, 3 and displayed in Figure 3. $\mathrm{Rb}$ and $\mathrm{Sr}$ concentrations and $\mathrm{Sr}$ isotopic ratios are summarized in Tables 4, 5, Figure 4. To analyze $\mathrm{Sr}$ isotope ratios, especially for the samples with low $\mathrm{Sr}$ contents, the $\mathrm{Rb} / \mathrm{Sr}$ ratio and $\mathrm{Rb}$ content do matter. The $\mathrm{Rb} / \mathrm{Sr}$ ratios of clinopyroxene are normally below 0.01 ; thus, the radiogenic ${ }^{87} \mathrm{Sr}$ contribution is insignificant (Yang et al., 2011, 2014, 2019; Tong et al., 2016; Zhang et al., 2018). In this research, the $\mathrm{Rb} / \mathrm{Sr}$ ratios of samples fall in a range of 0.001-0.005.

\section{CPX With About $300 \mu \mathrm{g} \mathrm{g}^{-1}$ Sr Content (JJG1424 and YY09-47)}

Samples JJG1424 and YY09-47 have Sr content of 309.6 and $344.2 \mu \mathrm{g} \mathrm{g}^{-1}$, respectively. They show narrow varieties of elemental ranges and have $\mathrm{Rb} / \mathrm{Sr}$ ratio of $0.0015-0.0017$ (Table 4). Approximately 120 analyses were performed on each sample in five sessions, with the signal intensity of the ${ }^{88} \mathrm{Sr}$ between 0.7 and $3.0 \mathrm{~V}$. Overall, the measured ${ }^{87} \mathrm{Sr} /{ }^{86} \mathrm{Sr}$ values for JJG1424 fell in the range of 0.70481 to 0.70506 , and for YY09-47, from 0.70401 to 0.70408 under different instrumental conditions in five separate sessions (Table 4, Figures 4A,B). The stable isotope ${ }^{84} \mathrm{Sr} /{ }^{86} \mathrm{Sr}$ is $0.0573 \pm 0.0012$ (2SD, $n=102$ ) for JJG1424 and $0.0563 \pm 0.0021(2 \mathrm{SD}, n=124)$ for YY09-47, respectively. Multiple in situ analysis of these clinopyroxenes over a period of 2 years gave average ${ }^{87} \mathrm{Sr} /{ }^{86} \mathrm{Sr}=0.70494 \pm 0.00031$ 
TABLE 5 | Comparison of $\mathrm{Rb}, \mathrm{Sr}$ content and ${ }^{87} \mathrm{Sr} /{ }^{86} \mathrm{Sr}$ ratios of clinopyroxene using ID-TIIMS and LA-(MC)-ICP-MS.

\begin{tabular}{lllllll}
\hline Sample & $\mathbf{R b}\left(\boldsymbol{\mu} \mathbf{g ~ g}^{-1}\right)$ & $\mathbf{S r}\left(\boldsymbol{\mu} \mathbf{g ~ g}^{-\mathbf{1}}\right)$ & ${ }^{87} \mathbf{S r} /{ }^{86} \mathbf{S r}$ & $\mathbf{2 s}$ & $\boldsymbol{n}$ & Methods \\
\hline JJG1424* & 0.16 & 309.6 & 0.704950 & 0.000030 & 1 & Solution \\
& 0.12 & 310 & 0.70494 & 0.00031 & 102 & Laser \\
YY09-47 & 0.20 & 344.2 & 0.704052 & 0.000010 & 1 & Solution \\
& 0.87 & 389 & 0.70405 & 0.00021 & 124 & Laser \\
YY09-04 & 0.21 & 222.4 & 0.703405 & 0.000010 & 1 & Solution \\
& 3.33 & 236 & 0.70334 & 0.00041 & 81 & Laser \\
YY09-24 & 0.30 & 200.6 & 0.703584 & 0.000010 & 1 & Solution \\
& 1.86 & 231 & 0.70349 & 0.00037 & 102 & Laser \\
YY12-01 & 0.09 & 192.1 & 0.703576 & 0.000014 & 1 & Solution \\
& 0.66 & 237 & 0.70358 & 0.00043 & 99 & Laser \\
YY12-02 & 0.09 & 52.6 & 0.703486 & 0.000010 & 1 & Solution \\
& 0.40 & 54 & 0.70328 & 0.00103 & 89 & Laser \\
\hline
\end{tabular}

*Means data comes from LeRoux et al. (2014) and was determined by solution MC-ICP-MS

(2SD, $n=102)$ and ${ }^{87} \mathrm{Sr} /{ }^{86} \mathrm{Sr}=0.70405 \pm 0.00021$ (2SD, $n$ $=124$ ), in good agreement with the result from MC-ICP-MS solution analysis $(0.70495 \pm 0.00003,2 \sigma, n=3$, LeRoux et al., 2014) and TIMS solution analysis $(0.704052 \pm 0.000010,2 \sigma, n=$ 1 ), respectively. Analytical $2 \sigma$ uncertainties during sessions 1-5 in each session were between 0.00013 and 0.00034 (Table 5).

\section{CPX With About $200 \mu \mathrm{g} \mathrm{g}^{-1} \mathrm{Sr}$ Contents (YY09-04, YY09-24, and YY12-01)}

Samples YY09-04, YY09-24, and YY12-01 have about $200 \mu \mathrm{g}$ $\mathrm{g}^{-1} \mathrm{Sr}$ (i.e., 222.4, 200.6, $192.1 \mu \mathrm{g} \mathrm{g}^{-1}$ ). They show narrow varieties of element ranges and have $\mathrm{Rb} / \mathrm{Sr}$ ratios under 0.0015 (Table 4). About 100 analyses were performed on each sample in session $1,2,3,4$, and 5 , totally, with the intensity of the ${ }^{88} \mathrm{Sr}$ signal between 0.4 and $1.7 \mathrm{~V}$. Overall, the measured ${ }^{87} \mathrm{Sr} /{ }^{86} \mathrm{Sr}$ values for YY09-04 fluctuated from 0.70321 to 0.70345 ; for YY0924, from 0.70333 to 0.70359 ; and for YY12-01, from 0.70338 to 0.70369 under different instrumental conditions in five separate sessions (Table 4, Figures 4C,D,F). The stable isotope ${ }^{84} \mathrm{Sr} /{ }^{86} \mathrm{Sr}$ is $0.0568 \pm 0.0030$ ( $2 \mathrm{SD}, n=81), 0.0565 \pm 0.0031$ ( $2 \mathrm{SD}, n=$ $102)$ and $0.0568 \pm 0.0029$ (2SD, $n=99)$, respectively. Multiple in situ analyses of these clinopyroxenes obtained over 2 years gave average values of ${ }^{87} \mathrm{Sr} /{ }^{86} \mathrm{Sr}=0.70334 \pm 0.00041$ (2SD, $n$ $=81)$ for YY09-04, ${ }^{87} \mathrm{Sr} /{ }^{86} \mathrm{Sr}=0.70349 \pm 0.00037(2 \mathrm{SD}, n=$ 102) for YY09-24, and ${ }^{87} \mathrm{Sr} /{ }^{86} \mathrm{Sr}=0.70358 \pm 0.00043$ (2SD, $n$ $=99$ ) for YY12-01, which matched well with the result from solution analysis $(0.703405 \pm 0.000010,2 \sigma, n=1 ; 0.703584 \pm$ $0.000010,2 \sigma, n=1 ; 0.703576 \pm 0.000014,2 \sigma, n=1)$. Analytical $2 \sigma$ uncertainties during session $1-5$ in each session were between 0.00025 and 0.00051 (Table 5).

\section{CPX With About $50 \mu \mathrm{g} \mathrm{g}^{-1}$ Sr Contents (YY12-02)}

Sample YY12-02 has the lowest Sr content $\left(52.6 \mu \mathrm{g} \mathrm{g}^{-1}\right)$ of the six samples and $\mathrm{ab} / \mathrm{Sr}$ ratio of 0.0017 (Table 4). Seventeen, 17, 15,16 , and 21 measurements were performed on the sample in sessions $1,2,3,4$, and 5 , respectively, with the signal intensity of the ${ }^{88} \mathrm{Sr}$ between 0.15 and $0.5 \mathrm{~V}$. In total, the measured ${ }^{87} \mathrm{Sr} /{ }^{86} \mathrm{Sr}$ values for YY12-02 ranged from 0.70295 to 0.70361 under different instrumental conditions in five separate sessions (Table 4, Figure 4F). The stable isotope ${ }^{84} \mathrm{Sr} /{ }^{86} \mathrm{Sr}$ is $0.0561 \pm$ 0.0106 (2SD, $n=89$ ). Multiple in situ analysis over a period of 2 years gave mean ${ }^{87} \mathrm{Sr} /{ }^{86} \mathrm{Sr}=0.70328 \pm 0.00103(2 \mathrm{SD}, n$ $=89$ ), which marginally falls within errors of the result from solution analysis $(0.703486 \pm 0.000010,2 \sigma, n=1)$. Analytical $2 \sigma$ uncertainties during session $1-5$ in each session were between 0.00082 and 0.00115 (Table 5).

\section{In situ Sr Isotopic Measurement of Low Sr Content Clinopyroxene}

As mentioned above, it is still challenging when it comes to reliably determining $\mathrm{Sr}$ isotope compositions of samples with low Sr content of $<100 \mu \mathrm{g} \mathrm{g}^{-1}$ (Sun et al., 2012; Tong et al., 2016). While performing Sr isotopic measurements, sensitivities vary due to instrumental conditions and parameters. Figure 5 shows variations in ${ }^{87} \mathrm{Sr} /{ }^{86} \mathrm{Sr}$ results for analyses, under identical instrumental condition, of NBS 987 solutions at variable ${ }^{88} \mathrm{Sr}$ signal intensity between 0.1 and $10 \mathrm{~V}$. This suggests that, although the ${ }^{87} \mathrm{Sr} /{ }^{86} \mathrm{Sr}$ results deviate from the reference value as the signal drops, the longer integration time $(1.049 \mathrm{~s})$ can compensate and improve the precision. This improvement is especially pronounced when the intensity is lower than $0.5 \mathrm{~V}$.

As summarized in Table 4, when the signal of the sample is lower than $1 \mathrm{~V}$, particularly for samples with low Sr content (e.g., about $100 \mu \mathrm{g} \mathrm{g}^{-1} \mathrm{Sr}$ ). We utilized line scanning instead of single spot sampling in session $1(120 \mu \mathrm{m}$ spot size, nanosecond 193$\mathrm{nm}$ laser) and session 5 (60 $\mu \mathrm{m}$ spot size, femtosecond $257-\mathrm{nm}$ laser). Comparing with results of constant single point ablation, the ${ }^{88} \mathrm{Sr}$ signal intensity lifted to $1 \mathrm{~V}$, and the accuracy improved from 0.00051 (2SD, $n=20$ ) to 0.00022 (2SD, $n=20$ ). This reveals that we can get higher precision $\mathrm{Sr}$ isotopic data through nanosecond and femtosecond ablation by line scanning mode with moderate spot size even if the Sr content is $<100 \mu \mathrm{g} \mathrm{g}^{-1}$. Therefore, for low Sr content samples, raster rather than crater laser mode, combined with more integration time, is preferable and can promote the precision and accuracy of actual low clinopyroxene sample. Moreover, the ideal ${ }^{88} \mathrm{Sr}$ signal intensity is more than ca. $1 \mathrm{~V}$ for reliable ${ }^{87} \mathrm{Sr} /{ }^{86} \mathrm{Sr}$ data (Waight et al., 2002; Vroon et al., 2008; Jochum et al., 2009; Yang et al., 2014, 2019; Tong et al., 2016; Zhang et al., 2018).

\section{The Potential of Clinopyroxene for in situ Sr Isotopic Analysis}

As mentioned above, Figure 1 illustrates that over 65\% $(10,010 / 15,306)$ published clinopyroxenes $(n=15,306$, Georoc) have more strontium than YY12-02 sample with $50 \mu \mathrm{g} \mathrm{g}^{-1} \mathrm{Sr}$ content, more than $40 \%(6,077 / 15,306)$ clinopyroxene contain over $100 \mu \mathrm{g} \mathrm{g}^{-1}$ strontium, and over $90 \%(13,863 / 15,306)$ are $<350 \mu \mathrm{g} \mathrm{g}^{-1}$. Thus, clinopyroxene is a mineral that has low $\mathrm{Sr}$ content, and the suite of clinopyroxene reference materials have wide applicability and can cover the Sr content of the majority of natural clinopyroxenes. 

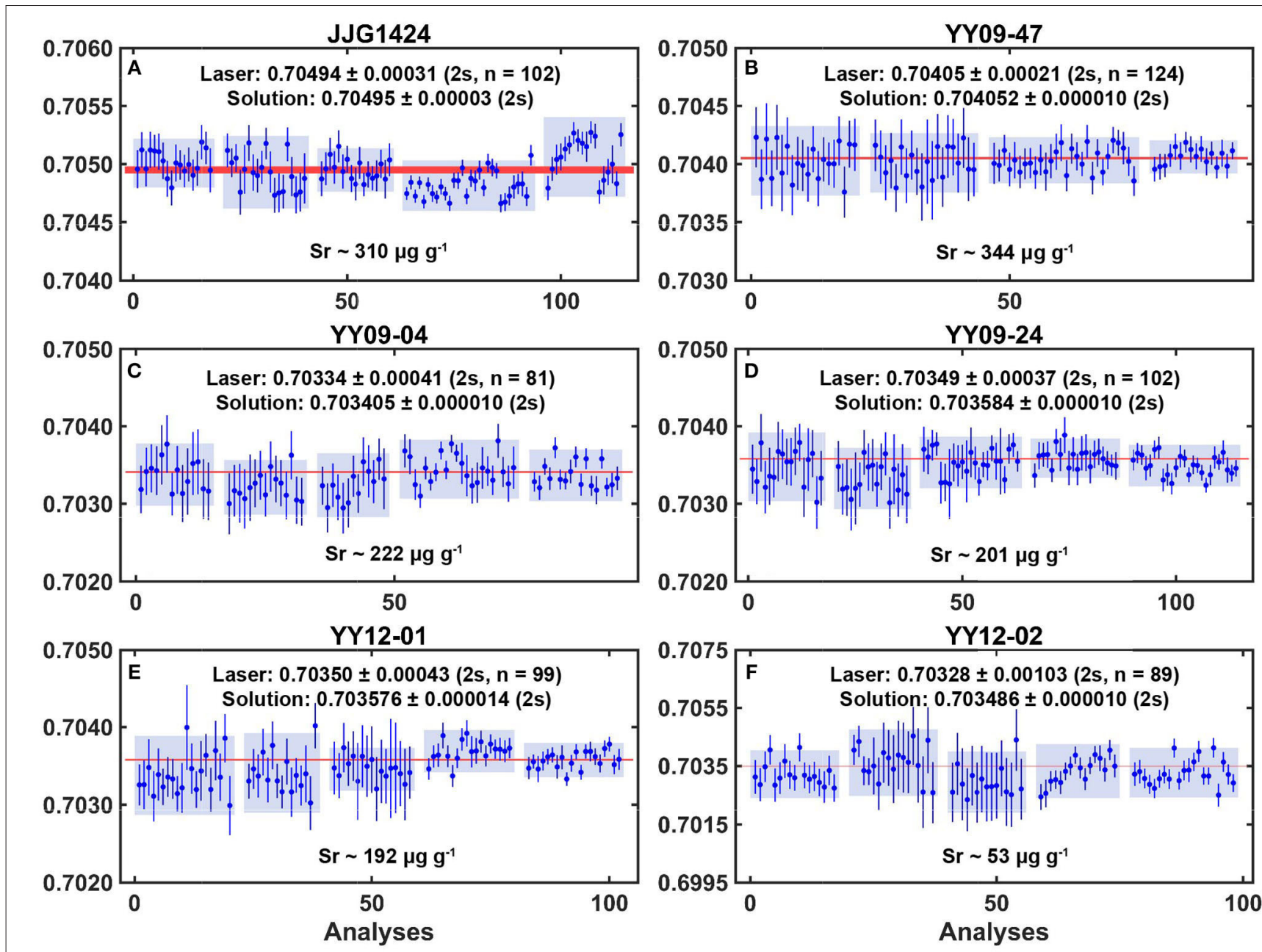

FIGURE 4 | The measured ${ }^{87} \mathrm{Sr} /{ }^{86} \mathrm{Sr}$ ratios of six clinopyroxene samples over 2-year periods. The five light blue rectangle areas of each separate figure exhibit two standard deviation and subtraction on mean value of five sessions. The light red linear areas show reference values (for A, reference value from solution MC-ICP-MS by LeRoux et al., 2014; for B-F, reference values determined by ID-TIMS). The error bars are two standard deviations.

Low element contents and isobaric interferences precluded $\mathrm{Sr}$ isotopic analysis on some clinopyroxene samples via LAMC-ICP-MS. Our previous study indicated that $\sim 500 \mu \mathrm{g} \mathrm{g}^{-1}$ $\mathrm{Sr}$ is enough to obtain an absolute precision of \pm 0.0001 on the ${ }^{87} \mathrm{Sr} /{ }^{86} \mathrm{Sr}$ ratio when using a large laser spot size (Yang et al., 2009b, 2014, 2019). The extremely low Rb contents (and hence very low $\mathrm{Rb} / \mathrm{Sr}$ ratios) of clinopyroxene mean that isobaric interference of ${ }^{87} \mathrm{Rb}$ on ${ }^{87} \mathrm{Sr}$ is usually negligible and can be easily accounted for (Yang et al., 2011). At more moderate to low Sr content of clinopyroxene $\left(200 \mu \mathrm{g} \mathrm{g}^{-1}\right)$, there is usually enough $\mathrm{Sr}$ for reasonable $\mathrm{Sr}$ isotopic analysis $( \pm 0.0002)$. In our experiences, the $\mathrm{Sr}$ content of clinopyroxene determines the signal insensitivity and is the major factor for reliable $\mathrm{Sr}$ isotopic measurement by LA-MC-ICP-MS of this mineral phase ( $\mathrm{Wu}$ et al., 2010; Yang et al., 2014, 2019; Zhang et al., 2018).

Based on our in situ Sr isotopic analyses of six potential clinopyroxene samples during 2-year periods (Figure 4, Table 5), we suggest that clinopyroxene with moderate Sr content ranging from 100 to $350 \mu \mathrm{g} \mathrm{g}^{-1}$ (e.g., JJG1424, YY09-47, YY09-04, YY09-24, and YY12-01) have statistically significant stability and homogeneity, making them excellent potential candidates for $\mathrm{Sr}$ isotopic microanalyses. Meanwhile, YY12-02 has lower content of elemental $\mathrm{Sr}$, and its ${ }^{87} \mathrm{Sr} /{ }^{86} \mathrm{Sr}$ varies slightly (but marginally within errors of TIMS value), therefore making it a potential clinopyroxene reference material for samples with low content of Sr (Waight et al., 2002; Vroon et al., 2008; Jochum et al., 2009; Yang et al., 2014, 2019; Tong et al., 2016; Zhang et al., 2020).

\section{CONCLUSIONS}

Considering the few, or unavailable, natural clinopyroxene reference materials for $\mathrm{Sr}$ microanalysis, we investigated thoroughly the assessment by both laser and solution measurements of the $\mathrm{Sr}$ isotopic ratios of six potential natural clinopyroxene reference materials from South Africa and China. The Sr isotopic compositions obtained for these samples 


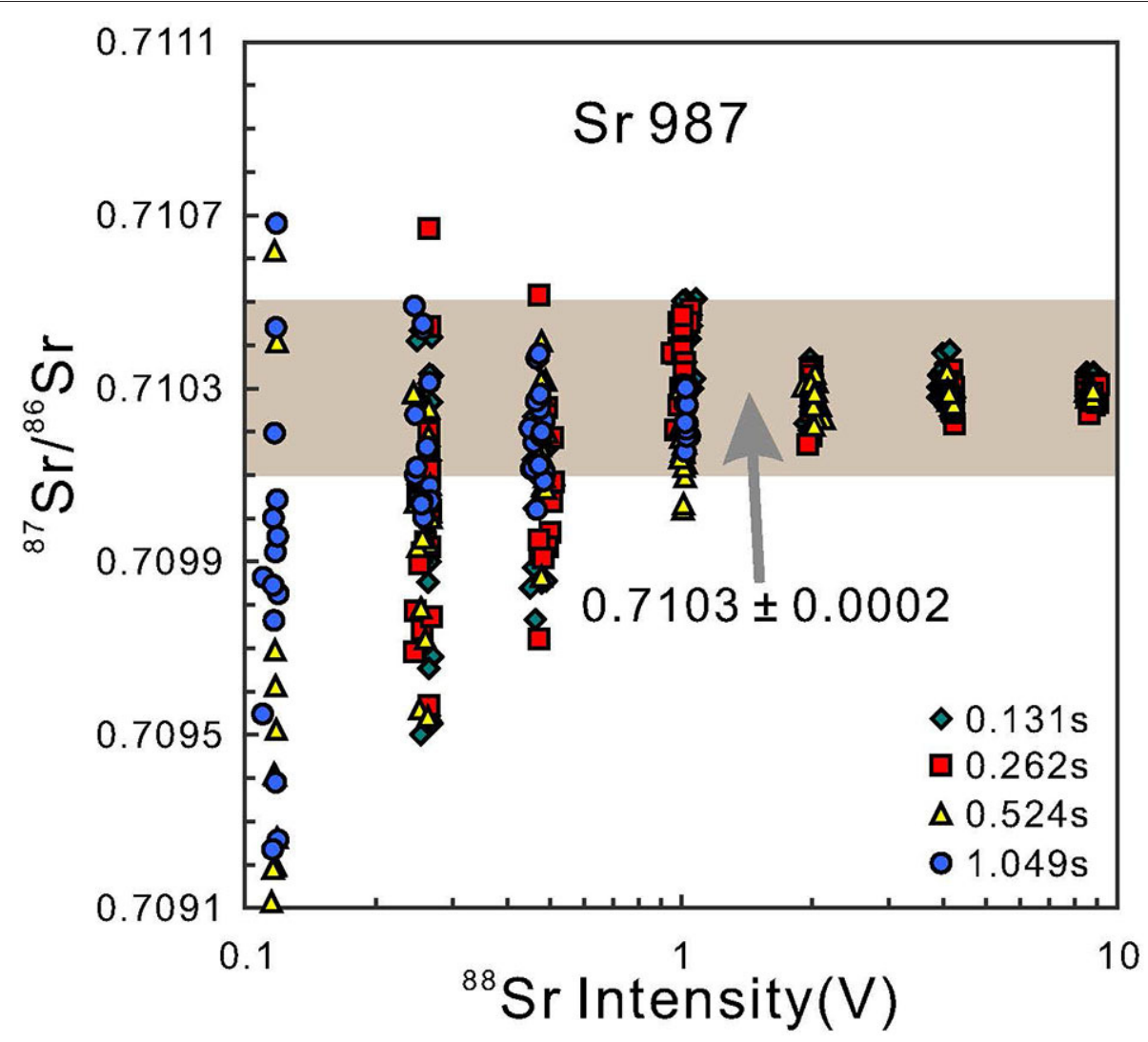

FIGURE 5 | The relationship between the variation of ${ }^{87} \mathrm{Sr} /{ }^{86} \mathrm{Sr}$ ratios of NBS 987 and ${ }^{88} \mathrm{Sr}$ signal intensity (volt) with different integration times, which simulate for low Sr content clinopyroxene sample under the similar laser mode and investigate the effect on accuracy and precision of low signal intensity using a Faraday cup. The gray rectangle means the accepted value of $0.7103 \pm 0.0002$ (2SD). The error bar is smaller than the symbol labels. As indicated, crater laser mode time can yield reasonable Sr isotope with of \pm 0.0002 on the ${ }^{87} \mathrm{Sr} /{ }^{86} \mathrm{Sr}$ ratio, for the moderate Sr contents of clinopyroxene (more than 200 ppm Sr). However, a raster laser mode together with more integration time is preferable and desirable over the crater mode because of the relatively low Sr content samples (ca. 100 ppm Sr). Moreover, the ideal ${ }^{88} \mathrm{Sr}$ signal intensity is more than ca. $1 \mathrm{~V}$ for reliable ${ }^{87} \mathrm{Sr} /{ }^{86} \mathrm{Sr}$ data.

are all consistent with values obtained by solution methods [both MC-ICP-MS and isotope dilution TIMS (ID-TIMS)]. Moreover, the major and trace elements of these clinopyroxenes were also examined by EPMA as well as solution and laser ICP-MS. Due to the abundant supply of these natural samples and their homogeneous $\mathrm{Sr}$ isotopic compositions, these clinopyroxene samples (JJG1424, YY09-47, YY09-04, YY09-24, and YY12-01) might be potential reference materials for in situ LA-MC-ICP-MS Sr isotopic measurements, and YY12-02 is a potential material to monitor analysis quality for low-Sr samples. Our results demonstrate that these samples can be employed as reference material for in situ determination of $\mathrm{Sr}$ concentration and isotope composition using laser sampling. Based on our data, laser ablation can yield reasonable $\mathrm{Sr}$ isotope with $2 \sigma$ precision of \pm 0.0002 on the ${ }^{87} \mathrm{Sr} /{ }^{86} \mathrm{Sr}$ ratio for clinopyroxene with moderate $\mathrm{Sr}$ contents (more than 200 $\mu \mathrm{g} \mathrm{g}^{-1} \mathrm{Sr}$ ). Moreover, our diverse investigation indicates that the raster laser mode is preferable over the crater mode when analyzing samples with relatively low Sr content (ca. $100 \mu \mathrm{g}$ $\mathrm{g}^{-1} \mathrm{Sr}$ ). These reference materials are of sufficient amount and are available to the scientific community via contacting the corresponding author.

\section{DATA AVAILABILITY STATEMENT}

The raw data supporting the conclusions of this article will be made available by the authors, without undue reservation.

\section{AUTHOR CONTRIBUTIONS}

$\mathrm{HZ}$ is a research scholar working on this study as part of his doctoral thesis, executed main experiments (major, trace, and $\mathrm{Sr}$ isotopes), analyzed and compiled the findings, and written this original manuscript preparation. X-MZ provided the five YangYuan samples and conducted trace element using solution ICP-MS and Sr isotope data by ID-TIMS. PL provided the JJG1424 sample and totally went through the draft. WZ is in charge of fs-LA-MC-ICP-MS at GPMR, Wuhan, conducted instrumental tuning, and supervised the fs-LA-MC-ICP MS work of HZ. L-WX, CH, and S-TW helped with the initial screening of CPX samples potentially suitable for LA-ICP-MS and ID-TIMS. $\mathrm{HW}, \mathrm{J}-\mathrm{HY}$, and F-YW reviewed the draft and gave insightful comments. Y-HY supervised the whole study from planning to execution and result analysis. All authors contributed to the article and approved the submitted version. 


\section{FUNDING}

This study was financially supported by the Natural Science Foundation of China (Grants 41525012 and 41973015).

\section{ACKNOWLEDGMENTS}

We thank Mao Q. and Zhang D. for their assistance with EPMA analysis. We are also grateful to the

\section{REFERENCES}

Achterbergh, E., van, Ryan, C. G., Jackson, S. E., and Griffin, W. L. (2001). "Data reduction software for LA-ICP-MS," in Laser-Ablation-ICPMS in Earth Sciences: Principles and Applications, Vol. 29, ed J. S. Paul (Ottowa, ON: Mineralogical Association of Canada),

Aulbach, S., Heaman, L. M., Jacob, D. E., and Viljoen, K. S. (2019). Ages and sources of mantle eclogites: ID-TIMS and in situ MC-ICPMS Pb-Sr isotope systematics of clinopyroxene. Chem. Geol. 503, 15-28. doi: 10.1016/j.chemgeo.2018.10.007

Bizzarro, M., Simonetti, A., Stevenson, R. K., and Kurszlaukis, S. (2003). In situ ${ }^{87} \mathrm{Sr} /{ }^{86} \mathrm{Sr}$ investigation of igneous apatites and carbonates using laser-ablation MC-ICP-MS. Geochim. Cosmochim. Acta 67, 289-302. doi: 10.1016/S0016-7037(02)01048-7

Christensen, J. N., Halliday, A. N., Lee, D. C., and Hall, C. M. (1995). In situ Sr isotopic analysis by laser ablation. Earth Planet. Sci. Lett. 136, 79-85. doi: 10.1016/0012-821X(95)00181-6

Chu, Z. Y., Wu, F. Y., Walker, R. J., Rudnick, R. L., Pitcher, L., Puchtel, I. S., et al. (2009). Temporal evolution of the lithospheric mantle beneath the eastern North China Craton. J. Petrol. 50, 1857-1898. doi: 10.1093/petrology/egp055

Class, C., and le Roex, A. P. (2011). South Atlantic DUPAL anomaly-dynamic and compositional evidence against a recent shallow origin. Earth Planet. Sci. Lett. 305, 92-102. doi: 10.1016/j.epsl.2011.02.036

Copeland, S. R., Sponheimer, M., le Roux, P. J., Grimes, V., Lee-Thorp, J. A., de Ruiter, D. J., et al. (2008). Strontium isotope ratios $\left({ }^{87} \mathrm{Sr} /{ }^{86} \mathrm{Sr}\right)$ of tooth enamel: a comparison of solution and laser ablation multicollector inductively coupled plasma mass spectrometry methods. Rapid Commun. Mass Spectrom. 22, 3187-3194. doi: 10.1002/rcm.3717

Deng, L., Liu, Y. S., Zong, K. Q., Zhu, L. Y., Xu, R., Hu, Z. C., et al. (2017). Trace element and $\mathrm{Sr}$ isotope records of multiepisode carbonatite metasomatism on the eastern margin of the North China Craton. Geochem. Geophys. Geosystem. 18, 220-237. doi: 10.1002/2016GC006618

Fietzke, J., Liebetrau, V., Günther, D., Gürs, K., Hametner, K., Zumholz, K., et al. (2008). An alternative data acquisition and evaluation strategy for improved isotope ratio precision using LA-MC-ICP-MS applied to stable and radiogenic strontium isotopes in carbonates. J. Anal. At. Spectrom 23, 955-961. doi: 10.1039/b717706b

Gao, J. F., and Zhou, M. F. (2013). Generation and evolution of siliceous high magnesium basaltic magmas in the formation of the Permian Huangshandong intrusion (Xinjiang, NW China). Lithos 162-163, 128-139. doi: 10.1016/j.lithos.2013.01.002

Griffin, W. L., and Brueckner, H. K. (1985). REE, Rb-Sr and Sm-Nd studies of Norwegian eclogites. Chem. Geol. Isotope Geosci. Sect. 52, 249-271. doi: 10.1016/0168-9622(85)90021-1

Hart, S. R., Ball, L., and Jackson, M. (2005). Sr Isotope by Laser Ablation PIMMS: Application to CPX from Samoan Peridotite Xenolths WHOI Plasma Facility Open File Technical Report, 11, Woods Hole Oceanographic Institution. Available online at: http://www.whoi.edu/science/GG/people/shart/open_file. htm

Horstwood, M. S. A., Evans, J. A., and Montgomery, J. (2008). Determination of $\mathrm{Sr}$ isotopes in calcium phosphates using laser ablation inductively coupled plasma mass spectrometry and their application to archaeological tooth enamel. Geochim. Cosmochim. Acta 72, 5659-5674. doi: 10.1016/j.gca.2008.08.016

Horstwood, M. S. A., Kosler, J., Gehrels, G., Jackson, S. E., McLean, N. M., Paton, C., et al. (2016). Community-derived standards for LAICP-MS U-(Th-) $\mathrm{Pb}$ geochronology - uncertainty propagation, age interpretation and data reporting. Geostandards Geoanal. Res. 40, 311-332. doi: 10.1111/j.1751-908X.2016.00379.x reviewers for their comments and suggestions to clarify our arguments.

\section{SUPPLEMENTARY MATERIAL}

The Supplementary Material for this article can be found online at: https://www.frontiersin.org/articles/10.3389/fchem. 2020.594316/full\#supplementary-material

Jackson, M. G., and Hart, S. R. (2006). Strontium isotopes in melt inclusions from Samoan basalts: implications for heterogeneity in the Samoan plume. Earth Planet. Sci. Lett. 245, 260-277. doi: 10.1016/j.epsl.2006.02.040

Jochum, K. P., Stoll, B., Weis, U., Kuzmin, D. V., and Sobolev, A. V. (2009). In situ Sr isotopic analysis of low Sr silicates using LA-ICP-MS. J. Anal. At. Spectrom. 24, 1237-1243. doi: 10.1039/b905045k

Kimura, J. I., Takahashi, T., and Chang, Q. (2013). A new analytical bias correction for in-situ $\mathrm{Sr}$ isotope analysis of plagioclase crystals using laser-ablation multiple-collector inductively coupled plasma mass spectrometry. J. Anal. At. Spectrom. 28, 945-957. doi: 10.1039/c3ja30329b

Konter, J. G., and Storm, L. P. (2014). High precision ${ }^{87} \mathrm{Sr} /{ }^{86} \mathrm{Sr}$ measurements by MC-ICP-MS, simultaneously solving for $\mathrm{Kr}$ interferences and mass-based fractionation. Chem. Geol. 385, 26-34. doi: 10.1016/j.chemgeo.2014.07.009

LeRoux, P. J., Lee-Thorp, J. A., Copeland, S. R., Sponheimer, M., and de Ruiter, D. J. (2014). Strontium isotope analysis of curved tooth enamel surfaces by laserablation multicollector ICP-MS. Palaeogeogr. Palaeoclimatol. Palaeoecol. 416, 142-149. doi: 10.1016/j.palaeo.2014.09.007

Li, C. F., Li, X. H., Li, Q. L., Guo, J. H., Li, X. H., and Yang, Y. H. (2012). Rapid and precise determination of $\mathrm{Sr}$ and $\mathrm{Nd}$ isotopic ratios in geological samples from the same filament loading by thermal ionization mass spectrometry employing a single-step separation scheme. Anal. Chim. Acta 727, 54-60. doi: 10.1016/j.aca.2012.03.040

Li, C. F., Wu, H. Q., Chu, Z. Y., Wang, X. C., Li, Y. L., and Guo, J. H. (2019). Precise determination of radiogenic $\mathrm{Sr}$ and $\mathrm{Nd}$ isotopic ratios and $\mathrm{Rb}, \mathrm{Sr}, \mathrm{Sm}, \mathrm{Nd}$ elemental concentrations in four coal ash and coal fly ash reference materials using isotope dilution thermal ionization mass spectrometry. Microchem. J. 146, 906-913. doi: 10.1016/j.microc.2019.02.034

Lin, J., Liu, Y. S., Chen, H. H., Zhou, L., Hu, Z. C., and Gao, S. (2015). Review of high-precision Sr isotope analyses of low-Sr geological samples. J. Earth Sci. 26, 763-774. doi: 10.1007/s12583-015-0593-0

Lin, J., Liu, Y. S., Yang, Y. H., and Hu, Z. C. (2016). Calibration and correction of LA-ICP-MS and LA-MC-ICPMS analyses for element contents and isotopic ratios. Solid Earth Sci. 1, 5-27. doi: 10.1016/j.sesci.2016.04.002

Liu, C. Z., Zhang, C., Xu, Y., Wang, J. G., Chen, Y., Guo, S., et al. (2016). Petrology and geochemistry of mantle peridotites from the Kalaymyo and Myitkyina ophiolites (Myanmar): implications for tectonic settings. Lithos 264, 495-508. doi: 10.1016/j.lithos.2016.09.013

McDonough, W. F., and Sun, S. S. (1995). The composition of the Earth. Chem. Geol. 120, 223-253. doi: 10.1016/0009-2541(94)00140-4

Norman, M. D. (2001). “Applications of laser ablation ICPMS to the trace element geochemistry of basaltic magmas and mantle evolution," in: Laser-AblationICPMS in the Earth Sciences, Vol. 29 (St. Johns, NL: Mineralogical Association of Canada), 163-184.

Raczek, I., Jochum, K. P., and Hofmann, A. W. (2003). Neodymium and strontium isotope data for USGS reference materials BCR-1, BCR-2, BHVO-1, BHVO2, AGV-1, AGV-2, GSP-1, GSP-2 and eight MPI-DING reference glasses, Geostand. Geoanal. Res. 27, 173-179. doi: 10.1111/j.1751-908X.2003.tb00644.x

Raddatz, J., Liebetrau, V., Rüggeberg, A., Hathorne, E., Krabbenhöft, A., Eisenhauer, A., et al. (2013). Stable Sr-isotope, $\mathrm{Sr} / \mathrm{Ca}, \mathrm{Mg} / \mathrm{Ca}, \mathrm{Li} / \mathrm{Ca}$ and $\mathrm{Mg} / \mathrm{Li}$ ratios in the scleractinian cold-water coral lophelia pertusa. Chem. Geol. 352, 143-152. doi: 10.1016/j.chemgeo.2013.06.013

Ramos, F. C., Wolff, J. A., and Tollstrup, D. L. (2004). Measuring ${ }^{87} \mathrm{Sr} /{ }^{86} \mathrm{Sr}$ variations in minerals and groundmass from basalts using LA-MC-ICPMS. Chem. Geol. 211, 135-158. doi: 10.1016/j.chemgeo.2004.06.025

Rudnick, R. L., Gao, S., Ling, W. L., Liu, Y. S., and McDonough, W. F. (2004). Petrology and geochemistry of spinel peridotite xenoliths from Hannuoba and Qixia, North China craton. Lithos 77, 609-637. doi: 10.1016/j.lithos.2004.03.033 
Sapienza, G. T., Griffin, W. L., O’Reilly, S. Y., and Morten, L. (2008). Petrology and $\mathrm{Sr}-\mathrm{Nd}-\mathrm{Hf}$ isotope geochemistry of gabbro xenoliths from the Hyblean Plateau: a MARID reservoir beneath SE Sicily? Contribut. Mineral. Petrol. 157, 1-22. doi: 10.1007/s00410-008-0317-x

Schmidberger, S. S., Simonetti, A., and Francis, D. (2003). Small-scale Sr isotope investigation of clinopyroxenes from peridotite xenoliths by laser ablation MCICP-MS-implications for mantle metasomatism. Chem. Geol. 199, 317-329. doi: 10.1016/S0009-2541(03)00125-6

Schmidberger, S. S., Simonetti, A., Heaman, L. M., Creaser, R. A., and Whiteford, S. (2007). Lu-Hf, in-situ $\mathrm{Sr}$ and $\mathrm{Pb}$ isotope and trace element systematics for mantle eclogites from the Diavik diamond mine: evidence for Paleoproterozoic subduction beneath the Slave craton, Canada. Earth Planet. Sci. Lett. 254, 55-68. doi: 10.1016/j.epsl.2006.11.020

Su, B. X., Gu, X. Y., Deloule, E., Zhang, H. F., Li, Q. L., Li, X. H., et al. (2015). Potential orthopyroxene, clinopyroxene and olivine reference materials for in situ lithium isotope determination. Geostand. Geoanal. Res. 39, 357-369. doi: 10.1111/j.1751-908X.2014.00313.x

Sun, J., Liu, C. Z., Wu, F. Y., Yang, Y. H., and Chu, Z. Y. (2012). Metasomatic origin of clinopyroxene in Archean mantle xenoliths from Hebi, North China Craton: Trace-element and Sr-isotope constraints. Chem. Geol. 328, 123-136. doi: 10.1016/j.chemgeo.2012.03.014

Tang, G. Q., Su, B. X., Li, Q. L., Xia, X. P., Jing, J. J., Feng, L. J., et al. (2019). High-Mg\# olivine, clinopyroxene and orthopyroxene reference materials for in situ oxygen isotope determination. Geostand. Geoanal. Res. 43, 585-593. doi: 10.1111 /ggr.12288

Tang, M., McDonough, W. F., and Ash, R. D. (2017). Europium and strontium anomalies in the MORB source mantle. Geochim. Cosmochim. Acta 197, 132-141. doi: 10.1016/j.gca.2016.10.025

Tang, Y. J., Zhang, H. F., Deloule, E., Su, B. X., Ying, J. F., Xiao, Y., et al. (2012). Slab-derived lithium isotopic signatures in mantle xenoliths from northeastern North China Craton. Lithos 149, 79-90. doi: 10.1016/j.lithos.2011.12.001

Tang, Y. J., Zhang, H. F., Nakamura, E., and Ying, J. F. (2011). Multistage melt/fluid-peridotite interactions in the refertilized lithospheric mantle beneath the North China Craton: constraints from the $\mathrm{Li}-\mathrm{Sr}-\mathrm{Nd}$ isotopic disequilibrium between minerals of peridotite xenoliths. Contribu. Mineral. Petrol. 161, 845-861. doi: 10.1007/s00410-010-0568-1

Tong, X. R., Liu, Y. S., Hu, Z. C., Chen, H. H., Zhou, L., Hu, Q. H., et al. (2016). Accurate determination of $\mathrm{Sr}$ isotopic compositions in clinopyroxene and silicate glasses by LA-MC-ICP-MS. Geostand. Geoanal. Res. 40, 85-99. doi: 10.1111/j.1751-908X.2015.00315.x

Touron, S., Renac, C., O’Reilly, S. Y., Cottin, J. Y., and Griffin, W. L. (2008). "Characterization of the metasomatic agent in mantle xenoliths from Deves, Massif Central (France) using coupled in situ trace-element and $\mathrm{O}, \mathrm{Sr}$ and $\mathrm{Nd}$ isotopic compositions," in: Metasomatism in Oceanic and Continental Lithospheric Mantle. Geological Society. eds M. Coltorti and M. Grégoire (London: Special Publications), 293, 177-196. doi: 10.1144/SP293.9

Vroon, P. Z., van der, Wagt, B., Koornneef, J. M., and Davies, G. R. (2008). Problems in obtaining precise and accurate $\mathrm{Sr}$ isotope analysis from geological materials using laser ablation MC-ICPMS. Anal. Bioanal. Chem. 390, 465-476. doi: 10.1007/s00216-007-1742-9

Waight, T., Baker, J., and Peate, D. (2002). Sr isotope ratio measurements by double-focusing MC-ICPMS: Techniques, observations and pitfalls. Int. J. Mass Spectrom. 221, 229-244. doi: 10.1016/S1387-3806(02)01016-3

Woodhead, J., Swearer, S., Hergt, J., and Maas, R. (2005). In-situ Sr isotope analysis of carbonates by LA-MC-ICP-MS: interference corrections, high spatial resolution and an example from otolith studies. J. Anal. At. Spectrom. 20, 22-27. doi: 10.1039/b412730g

Wu, F. Y., Walker, R. J., Yang, Y. H., Yuan, H. L., and Yang, J. H. (2006). The chemical-temporal evolution of lithospheric mantle underlying the North China Craton. Geochim. Cosmochim. Acta 70, 5013-5034. doi: 10.1016/j.gca.2006.07.014

Wu, F. Y., Yang, Y. H., Marks, M. A. W., Liu, Z. C., Zhou, Q., Ge, W. C., et al. (2010). In situ $\mathrm{U}-\mathrm{Pb}, \mathrm{Sr}, \mathrm{Nd}$, and $\mathrm{Hf}$ isotopic analysis of eudialyte by LA-(MC)ICP-MS. Chem. Geol. 273, 8-34. doi: 10.1016/j.chemgeo.2010.02.007

Xu, J., Yang, S. Y., Yang, Y. H., Liu, Y. S., and Xie, X. L. (2020). Precise determination of stable strontium isotopic compositions by MC-ICP-MS. Atomic Spectrosc. 41, 57-66. doi: 10.46770/AS.2020.02.003
Xu, R., Liu, Y. S., Tong, X. R., Hu, Z. C., Zong, K. Q., and Gao, S. (2013). In-situ trace elements and $\mathrm{Li}$ and $\mathrm{Sr}$ isotopes in peridotite xenoliths from Kuandian, North China Craton: insights into Pacific slab subduction-related mantle modification. Chem. Geol. 354, 107-123. doi: 10.1016/j.chemgeo.2013.06.022

Xu, Y. G., Menzies, M. A., Thirlwall, M. F., Huang, X. L., Liu, Y., et al. (2003). "Reactive" harzburgites from Huinan, NE China: products of the lithosphere asthenosphere interaction during lithospheric thinning? Geochim. Cosmochim. Acta 67, 487-505. doi: 10.1016/S0016-7037(02)01089-X

Yang, Y. H., Wu, F. Y., Li, Q. L., Rojas-Agramonte, Y., Yang, J. H., Li, Y., et al. (2019). In situ U-Th-Pb dating and Sr-Nd isotope analysis of bastnasite $e$ by LA(MC)-ICP-MS. Geostand. Geoanal. Res. 43, 543-565. doi: 10.1111/ggr.12297

Yang, Y. H., Wu, F. Y., Liu, Z. C., Chu, Z. Y., Xie, L. W., and Yang, J. H. (2012). Evaluation of $\mathrm{Sr}$ chemical purification technique for natural geological samples using common cation-exchange and Sr-specific extraction chromatographic resin prior to MC-ICP-MS or TIMS measurement. J. Anal. At. Spectrom. 27, 516-522. doi: 10.1039/c2ja10333h

Yang, Y. H., Wu, F. Y., Wilde, S. A., Liu, X. M., Zhang, Y. B., Xie, L. W., et al. (2009a). In situ perovskite Sr-Nd isotopic constraints on the petrogenesis of the Ordovician Mengyin kimberlites in the North China craton. Chem. Geol. 264, 24-42. doi: 10.1016/j.chemgeo.2009.02.011

Yang, Y. H., Wu, F. Y., Xie, L. W., Chu, Z. Y., and Yang, J. H. (2014). Reevaluation of interferences of doubly charged ions of heavy rare earth elements on $\mathrm{Sr}$ isotopic analysis using multi-collector inductively coupled plasma mass spectrometry. Spectrochim. Acta Part Atomic Spectrosc. 97, 118-123. doi: 10.1016/j.sab.2014.05.006

Yang, Y. H., Wu, F. Y., Xie, L. W., Yang, J. H., and Zhang, Y. B. (2011). Highprecision direct determination of the ${ }^{87} \mathrm{Sr} /{ }^{86} \mathrm{Sr}$ isotope ratio of bottled $\mathrm{Sr}$-rich natural mineral drinking water using multiple collector inductively coupled plasma mass spectrometry. Spectrochim. Acta B Atomic Spectrosc. 66, 656-660. doi: 10.1016/j.sab.2011.07.004

Yang, Y. H., Zhang, H. F., Chu, Z. Y., Xie, L. W., and Wu, F. Y. (2010). Combined chemical separation of $\mathrm{Lu}, \mathrm{Hf}, \mathrm{Rb}, \mathrm{Sr}, \mathrm{Sm}$ and $\mathrm{Nd}$ from a single rock digest and precise and accurate isotope determinations of Lu-Hf, $\mathrm{Rb}-\mathrm{Sr}$ and $\mathrm{Sm}-\mathrm{Nd}$ isotope systems using Multi-Collecter ICP-MS and TIMS. Int. J. Mass Spectrom. 290, 120-126. doi: 10.1016/j.ijms.2009.12.011

Yang, Y. H., Wu, F. Y., Xie, L. W., Yang, J. H., and Zhang, Y. B. (2009b). In situ Sr isotopic measurement of natural geological samples by LA-MC-ICP-MS. Acta Petrol. Sinica 25, 3431-3441. doi: 10.1016/S1874-8651(10)60080-4

Zhang, W., Hu, Z. C., and Liu, Y. S. (2020). Iso-compass: new freeware software for isotopic data reduction of LA-MC-ICP-MS. J. Anal. At. Spectrom. 35, 1087-1096. doi: 10.1039/D0JA00084A

Zhang, W., Hu, Z. C., Liu, Y. S., Wu, T., Deng, X. D., Guo, J. L., et al. (2018). Improved in situ $\mathrm{Sr}$ isotopic analysis by a $257 \mathrm{~nm}$ femtosecond laser in combination with the addition of nitrogen for geological minerals. Chem. Geol. 479, 10-21. doi: 10.1016/j.chemgeo.2017.12.018

Zhao, X. M., Zhang, H. F., Zhu, X. K., Zhu, B., and Cao, H. H. (2015). Effects of melt percolation on iron isotopic variation in peridotites from, Yangyuan, North China Craton. Chem. Geol. 401, 96-110. doi: 10.1016/j.chemgeo.2015.02.031

Zhao, X. M., Zhang, Z. F., Huang, S. C., Liu, Y. F., Li, X., and Zhang, H. F. (2017). Coupled extremely light $\mathrm{Ca}$ and $\mathrm{Fe}$ isotopes in peridotites. Geochim. Cosmochim. Acta 208, 368-380. doi: 10.1016/j.gca.2017.03.024

Zou, D. Y., Liu, Y. S., Hu, Z. C., Gao, S., Zong, K. Q., Xu, R., et al. (2014). Pyroxenite and peridotite xenoliths from Hexigten, inner Mongolia: insights into the Paleo-Asian Ocean subduction related melt/fluid-peridotite interaction. Geochim. Cosmochim. Acta 140, 435-454. doi: 10.1016/j.gca.2014.05.046

Conflict of Interest: The authors declare that the research was conducted in the absence of any commercial or financial relationships that could be construed as a potential conflict of interest.

Copyright (C) 2020 Zhao, Zhao, Le Roux, Zhang, Wang, Xie, Huang, Wu, Yang, Wu and Yang. This is an open-access article distributed under the terms of the Creative Commons Attribution License (CC BY). The use, distribution or reproduction in other forums is permitted, provided the original author(s) and the copyright owner(s) are credited and that the original publication in this journal is cited, in accordance with accepted academic practice. No use, distribution or reproduction is permitted which does not comply with these terms. 